\title{
Influence of topical and oral zinc upon corneal wound healing
}

\author{
GEORGE B. HUBBARD, BRUGE E. HERRON, J. STEVENS ANDREWS, \\ AND JAMES H. ELLIOTT \\ From the Division of Ophthalmology (Surgery) and the Ophthalmic Laboratory, Vanderbilt University \\ School of Medicine, Nashville, Tennessee 37203, U.S.A.
}

Experimental evidence indicates that the healing rate of avascular penetrating corneal wounds is delayed when compared with vascularized penetrating corneal wounds or with wounds of other vascularized tissues (Gasset and Dohlman, I968; Howes, Sooy, and Harvey, 1929). This is exemplified clinically by a substantial number of postoperative wound healing complications which may occur after penetrating keratoplasty. The complications resulting from the prolonged period necessary for healing of avascular corneal wounds after penetrating keratoplasty are dehiscence of the wound margins, overriding of host-graft wound edges, anterior iris synechiae, iris prolapse, oedema of the donor corneal button, and even total extrusion of the graft. Each of these complications or any combination of them may be sufficient to compromise the viability of the donor endothelium and lead to graft rejection.

Although it is well known that topically administered corticosteroids have a deleterious effect on the healing of avascular corneal wounds, the majority of postoperative keratoplasty patients receive topical corticosteroids to prevent or ameliorate the postoperative ocular inflammatory response of the anterior segment. However, because of this hazard, topical corticosteroids are given either in sub-optimal doses necessary for achieving suppression of the inflammatory response, or the drug is withheld during the immediate post-transplant period. Therefore, an agent which would accelerate the healing of avascular corneal wounds or nullify the adverse effects of topical corticosteroids on wound healing would be clinically valuable.

In the past many agents have been studied to determine if they are capable of enhancing corneal wound healing, with limited success (Rigg and Rigg, I959; Thomas, I955). Recently, systemically administered zinc has been shown to promote wound healing in both animals and man (Pories and Strain, I966; Pories, Henzel, Rob, and Strain, I967a, b; Strain, Pories, and Hinshaw, I960; Savlov, Strain, and Heugin, 1962). The effect of topical antiseptics, including zinc sulphate, upon regeneration of corneal epithelium has been reported (Bellows, I946); however, the effect of zinc on penetrating corneal wounds has not been studied.

The present study was therefore conducted to evaluate the effect of topically and systemically administered zinc preparations upon the tensile strength of avascular corneal wounds. All experiments were done in a blind fashion unless otherwise noted. Under the experimental conditions employed, statistical analysis of the data shows that the healing of avascular corneal wounds is neither promoted nor retarded by zinc. 


\section{Material and methods}

ANIMALS

New Zealand albino rabbits weighing $\mathrm{I} \cdot 8$ to $2 \cdot 3 \mathrm{~kg}$. (4 to $5 \mathrm{lb}$.) were used in all experiments. The were five groups, with ten rabbits in each group.

CORNEAL WOUNDS

Anaesthesia was achieved with intravenously administered pentobarbital sodium (Diabutal) in dose of $30 \mathrm{mg}$. $\mathrm{kg}$. body weight. This was supplemented by topically applied proparacaine hydr $\vec{\oplus}$ chloride (Ophthaine). The technique for the linear penetrating central corneal wound was that previously reported (Elliott and Leibowitz, i966) with certain modifications. After the cornea w. marked with two parallel lines, a $9 \mathrm{~mm}$. non-penetrating incision was made in order to allow pro placement of two black silk (7-0) Stallard type sutures (Fink and Barras, 1956) approximately 5 mrio apart and looped out of the way. The wound was then completed, resulting in a $9 \mathrm{~mm}$. penetratirs incision, and the sutures were pulled down and tied. Since Aquavella, Gasset, and Dohlman (196) observed an effect upon the contralateral control eye from systemic medications, the operative procedure was unilateral in all cases.

Following the surgical procedure, polymyxin B 5,000 units $/ \mathrm{ml}$, neomycin sulphate $2.5 \mathrm{mg} . / \mathrm{mE}$ gramicidin $0.025 \mathrm{mg} . / \mathrm{ml}$. (Neosporin Ophthalmic solution) were dropped liberally on the wounÆ. Thrice daily thereafter Io per cent. phenylephrine and I per cent. cyclopentolate were instilled $\stackrel{\oplus}{\mathrm{D}}$ all wounded eyes. All animals were observed daily. Eyes in both the experimental and the control group were eliminated from the study if there was evidence of infection, anterior synechia, gross vascularization, or delayed flattening of the anterior chamber.

MEASUREMENT OF TENSILE STRENGTH

The method described by Gasset and Dohlman (1968) was used to determine the corneal woun tensile strength. All tensile strength measurements in control and experimental groups were dor on the i ith postoperative day.

DRUG ADMINISTRATION

The drug regimen in each case was started on the day after corneal wounding and continued ung the day of the measurement of tensile strength. Five groups of ten animals each were used:

(I) These received two drops of Zincfrin (zinc sulphate 0.25 per cent., phenylephrine $\mathrm{HCl} \mathrm{o} \cdot \frac{\mathrm{O}}{\mathrm{B}}$ per cent., benzalkonium chloride $\mathbf{I} / \mathbf{I} 0,000$, barbital $0 \cdot 26$ per cent., barbital sodium $0 \cdot 13$ per cento) three times a day. It was estimated that each animal was given $0 \cdot 4 \mathrm{mg}$. elemental zinc per day in the operated eye. They were also given approximately $0.03 \mathrm{~g}$. Neosporin Ophthalmic Ointme (polymyxin B 5,000 units/g., zinc bacitracin $400 \mathrm{units} / \mathrm{g}$., neomycin sulphate $5 \mathrm{mg} \cdot / \mathrm{g}$.) once dail

(2) These were treated as a blind control with Group I. The only difference was that Group? received topical drops containing all the components of Zincfrin except the zinc sulphate (Zincfres diluent).

(3) These were given a daily oral dose of $725 \mathrm{mg}$. zinc sulphate in $\mathrm{I} \mathrm{ml}$. distilled water, whi满 contained approximately $165 \mathrm{mg}$. elemental zinc $(80 \mathrm{mg} . / \mathrm{kg}$.). It has been shown that $300 \mathrm{mg} . / \mathrm{kg}$ zinc is toxic to a rabbit, and that $8 \mathrm{o} \mathrm{mg}$. $\mathrm{kg}$. causes a significant rise in the plasma zinc level (Bere fenstam, 1952). These animals also received the topical drops without zinc sulphate as well as tion Neosporin ointment in the same dosage.

(4) These were treated as a blind control for Group 3, and received the same treatment, exce that the oral distilled water contained no added zinc sulphate. 
(5) In order to consider the possible effect that the trace amount of zinc (0.015 mg.) in the daily dose of Neosporin ointment might have on healing, this additional control group received Zincfrin diluent and a similar antibiotic ointment, Mycitracin (polymyxin B 5,000 units/g., bacitracin 500 units/g., neomycin sulphate $5 \mathrm{mg} . / \mathrm{kg}$.), which contains no zinc.

\section{Results}

The tensile strengths of the wounds for the fifty animals in the five groups mentioned above are shown in Table I.

Table I Tensile strength of corneal wounds in $\mathrm{g} . / 5 \mathrm{~mm}$. wound on the I I th postoperative day*

\begin{tabular}{|c|c|c|c|c|c|}
\hline Group & $\mathbf{I}$ & 2 & 3 & 4 & 5 \\
\hline Therapy & $\begin{array}{l}\text { Zincfrin } \\
(\mathrm{o} \cdot 4 \mathrm{mg} . \text { Zn/day }) \\
\text { Neosporin } \\
\text { ointment }\end{array}$ & $\begin{array}{l}\text { Zincfrin } \\
\text { diluent } \\
\text { Neosporin } \\
\text { ointment }\end{array}$ & $\begin{array}{l}\text { Oral Zn } \mathrm{SO}_{4} \\
\text { ( } 6_{5} \mathrm{mg} . \text { Zn/day) } \\
\text { Zincfrin diluent } \\
\text { Neosporin } \\
\text { ointment }\end{array}$ & $\begin{array}{l}\text { Oral distilled } \\
\text { water } \\
\text { Zincfrin diluent } \\
\text { Neosporin } \\
\text { ointment }\end{array}$ & $\begin{array}{l}\text { Zincfrin } \\
\text { diluent } \\
\text { Mycitracin } \\
\text { ointment }\left(\begin{array}{ll}\text { no } & Z n\end{array}\right)\end{array}$ \\
\hline \multirow{2}{*}{ Application } & \multicolumn{2}{|l|}{ Topical } & \multicolumn{2}{|l|}{ Oral } & \multirow{2}{*}{$\begin{array}{l}\text { Final } \\
\text { control }\end{array}$} \\
\hline & Zinc & Control & Zinc & Control & \\
\hline \multirow{14}{*}{$\begin{array}{l}\text { Tensile } \\
\text { strength } \\
\text { (g./5 mm.) }\end{array}$} & 100 & I 34 & 76 & 116 & 116 \\
\hline & 293 & 313 & 214 & 119 & I 55 \\
\hline & 291 & 167 & $6 \mathrm{I}$ & 132 & $35^{I}$ \\
\hline & 49 & 221 & 72 & 326 & 259 \\
\hline & I 79 & 63 & 244 & 263 & 188 \\
\hline & 138 & 130 & 101 & - & 107 \\
\hline & 195 & 205 & 225 & - & 99 \\
\hline & 65 & 102 & 225 & 一 & 164 \\
\hline & 216 & I 44 & 126 & 一 & 243 \\
\hline & 332 & 197 & $5^{I}$ & - & I 86 \\
\hline & I09 & 233 & - & 一 & 一 \\
\hline & 247 & - & - & 一 & 一 \\
\hline & I 59 & 一 & 一 & 一 & - \\
\hline & 247 & 一 & 一 & 一 & 一 \\
\hline Mean & $187 \pm 89$ & $174 \pm 70$ & $140 \pm 78$ & $191 \pm 97$ & $187 \pm 79$ \\
\hline
\end{tabular}

*All groups were done in blind fashion except Group 5

A formal analysis of these data to test whether there were statistically significant differences among the average tensile strengths for the five groups was carried out using analysis of variance (Table II). This confirms that the mean tensile strengths for the five groups were not significantly different in the statistical sense.

Table II Analysis of variance

\begin{tabular}{lcccc}
\hline Variance & $\begin{array}{l}\text { Degrees of } \\
\text { freedom }\end{array}$ & $\begin{array}{l}\text { Sums of } \\
\text { squares }\end{array}$ & $\begin{array}{l}\text { Mean } \\
\text { squares }\end{array}$ & $F$ \\
\hline Among treatments & 4 & I 7393 & $434^{8}$ & < I Not $\begin{array}{l}\text { Not } \\
\text { significant }\end{array}$ \\
$\begin{array}{l}\text { Within treatments } \\
\text { Among corneae }\end{array}$ & 45 & 299495 & 6655 & \\
\hline Total & 49 & 316888 & \\
\hline
\end{tabular}




\section{Comments}

The results presented demonstrate that in these dosages, zinc, both topically an systemically, has no significant effect on the normal healing processes of penetratin avascular corneal wounds.

Zinc has been found to be an essential part of several enzymes, including carbon $\frac{\overparen{C}}{\mathbf{E}}$ anhydrase, alkaline phosphatase, and various dehydrogenases. It also functions as $\frac{\sqrt[5]{\pi}}{\mathbb{D}}$ cofactor for many other enzymes (Underwood, i962). In the case of wound healing it has been proposed that zinc acts primarily at the wound site, where it may be incor porated into these enzyme systems (Pories and others, i967a, b).

There are several factors which must be considered in an analysis of the results. Althought high blood levels have been reported after similar oral zinc administration (Berfenstan I 962 ), perhaps because of the avascular nature of the cornea, there may not have beẹ̄i an increase in the zinc level at the site of the wound. Furthermore, when evaluating topical application it must be remembered that a corneal wound is covered by epitheliap cells within 24 hours (Hilding, I959). Since the epithelium is known to have a hig lipid content, which probably accounts for its preferential permeability to fat-solub substances, adequate penetration of the epithelium by the ionic topical solution may have been prevented. Use of an additional group of animals treated with subconjunctiva zinc salts to circumvent the epithelial barrier was planned; however, this experiment was not performed when we learned that zinc given subconjunctivally causes massiv sloughing and necrosis of conjunctival tissues (Gasset, A.R.: oral communication at the Association for Research in Ophthalmology meeting, Tampa, Florida, April 29, I968\$.

An additional consideration is the level of zinc which is normally present in the corne? Although the cornea is not rich in zinc in comparison with other ocular tissues (Bowneso, Morton, Shakir, and Stubbs, I952; Galin, Nano and Hall, r962), it may nevertheles already contain an optimal amount for wound repair. Thus, supplemental zinc wou厣 not be expected to cause a significant change in the wound healing rate.

\section{Summary}

Supplemental zinc, given both topically and systemically, failed to accelerate corne wound healing, as measured by the tensile strength of the wound on the eleventh postr. operative day.

The authors are grateful to Dr. Earl Maxwell, Alcon Research Laboratories, for supplying sterile, code and unlabelled Zincfrin and Zincfrin diluent.

Charles F. Federspiel, Ph.D., Assistant Professor of Biostatistics, Vanderbilt University School of Medicine assisted with the statistical analysis.

This investigation was supported by U.S. Public Health Service Research Grant NB-06977 and NB-069 from the National Institutes of Neurologic Diseases and Blindness and an unrestricted grant from Research Prevent Blindness, Inc.

\section{References}

AQuavella, J. v., Gasset, A. R., and dohlman, c. h. (ig64) Amer. 7. Ophthal., 58, 62 I Bellows, J. G. (1946) Arch. Ophthal. (Chicago), 36, 70 Berfenstam, R. (1952) Acta pediat., 41, Suppl. 87 (summary on p. 389 of vol. 4I) BOWness, J. M., MORTON, R. A., SHAKIR, M. H., and stubBs, A. L. (I952) Biochem. J., 51, 52 I elliott, J. H., and leibowitz, H. м. (ig66) Arch. Ophthal. (Chicago), 76, 334 Fink, A. I., and baras, I. (I956) Amer. 7. Ophthal., 42, 759 
GALIN, M. A., NANO, H. D., and HALl, T. (1962) Invest. Ophthal., I, 142 Gasset, A. R., and Dohlman, c. H. (ig68) Arch. Ophthal. (Chicago), 79, 595 Hilding, A. G. (i959) Amer. 7. Ophthal., 48, 787

howes, e. L., sooy, J. W., and harvey, s. c. (r929) 7. Amer. med. Ass., 92, 42

PORIES, W. J., HENZEL, J. H., ROB, c. G., and STRAin, w. H. (I967a) Lancet, r, I 2 I (1967b) Ann. Surg., r65, $43^{2}$

and strain, w. H. (Ig66) In “Zinc Metabolism", ed. A. S. Prasad, ist. ed., p. 378.

Thomas, Springfield, Ill.

RIGG, J. P., and RIGG, R. W. (I959) Amer. J. Ophthal., 48, no. I, pt 2, p. $23^{8}$

Savlov, E. D., strain, W. H., and huegin, F. (I962) J. surg. Res., 2, 209

STrain, W. H., PORIES, W. H., and hinshaW, J. R. (I960) Surg. Forum, I1, 29 I

тномаs, c. I. (1955) "The Cornea", ist ed., pp. 167-180. Thomas, Springfield, Ill.

UNDERWOOD, E. J. (I962) "Trace Elements in Human and Animal Nutrition", 2nd ed., p. I57.

Academic Press, New York 